\title{
PENGARUH PROFITABILITAS, KESULITAN KEUANGAN, UKURAN PERUSAHAAN DAN UMUR PERUSAHAAN TERHADAP KETEPATAN WAKTU PELAPORAN KEUANGAN EMITEN DI BURSA EFEK INDONESIA
}

\author{
IMELDA PURBA \\ Program Studi Akuntansi Universitas Katolik Santo Thomas Medan \\ imelda.rimenda.urba@gmail.cm
}

\begin{abstract}
ABSTRAK
Tujuan penelitian ini adalah untuk memperoleh bukti empiris adanya pengaruh antara variabel profitabilitas, kesulitan keuangan, ukuran perusahaan, dan umur perusahaan terhadap ketepatan waktu pelaporan keuangan pada perusahaan tambang pada periode 2016-2018. Jenis penelitian ini adalah penelitian kuantitatif.Data yang digunakan dalam penelitian ini adalah data sekunder.Populasi dalam penelitian ini mencakup semua perusahaan tambang yang terdaftar di BEI dalam periode 2016-2017. Sampel dalam penelitian ini sebanyak 17 perusahaan yang memenuhi kriteria, yaitu 13 perusahaan tepat waktu dalam penyampaian laporan keuangan sedang 4 diantaranya tidak tepat waktu. Teknik pengambilan sampel dalam penelitian ini menggunakan purposive sampling. Analisis data yang digunakan untuk menguji hipotesis adalah regresilogistik dengan tingkat signifikansi 5\% dan dengan menggunakan alat bantu SPSS versi 23. Hasil penelitian ini menunjukkan bahwa variabel profitabilitas, kesulitan keuangan, ukuran perusahaan, dan umur perusahaan secara simultan berpengaruh terhadap ketepatan waktu pelaporan keuangan.
\end{abstract}

Kata kunci: Profitabilitas, Kesulitan Keuangan, Ukuran Perusahaan, Umur Perusahaan dan Ketepatan Waktu Pelaporan Keuangan

\section{PENDAHULUAN}

Setiap perusahaan yang telah mencatatkan sahamnya di Bursa Efek Indonesia atau yang telah go public wajib menyampaikan informasi Laporan keuangan Tahunan, mengacu pada peraturan Bapepam Nomor :X.K.2 tahun 2002 dan menunjuk pada surat PT Bursa Efek Indonesia Nomor : S-134/BEI-PSR/02-2002 tanggal 14 Februari 2003 mengenai penerapan SE-02/PM/2002 menyangkut batas waktu penyampaian laporan keuangan tahunan ke Bapepam selambat-lambatnya pada akhir bulan ketiga (90 hari) setelah tanggal laporan keuangan tahunan

Kebutuhan akan ketepatan waktu dalam penyajian laporan keuangan kepada perusahaan publik di Indonesia telah diatur dalam UU No.8 Tahun 1995 tentang Pasar Modal. Tanggal 5 Juli 2011, Bapepam mengeluarkan lampiran Keputusan Ketua Bapepam dan LK Nomor: Kep346/BL/2011 Tentang Kewajiban Penyampaian Laporan Keuangan 
Berkala Emiten atau Perusahaan Publik yang menyatakan bahwa Laporan keuangan tahunan wajib disertai dengan laporan Akuntan dalam rangka audit atas laporan keuangan. Laporan keuangan tahunan wajib disampaikan kepada Bapepam dan LK dan diumumkan kepada masyarakat paling lambat pada akhir bulan ketiga (90 hari) setelah tanggal laporan keuangan tahunan.

Dalam pernyataan Standar Akuntansi keuangan (PSAK) No.1 paragraph 8 dikatakan bahwa karakteristik kualitatif laporan keuangan merupakan ciri khas yang membuat informasi dalam laporan keuangan berguna bagi pemakai. Terdapat 4 karakteristik pokok yaitu : dapat dipahami, relevan, keandalan dan dapat diperbandingkan. Dikatakan lebih lanjut dalam PSAK No.1 paragraph 43 : bahwa kendala informasi yang relevan dan andal adalah pelaporan tepat waktu. Jika terdapat penundaan yang tidak semestinya dalam pelaporan maka informasi yang dihasilkan akan kehilangan relevansinya. Untuk menyediakan informasi tepat waktu sering kali dibutuhkan melaporkan sebelum seluruh informasi dikumpulkan. Sebaliknya jika pelaporan ditunda sampai seluruh aspek diketahui, informasi yang dihasilkan mungkin sangat andal tetapi kurang bermanfaat bagi pengambil keputusan.

Dalam usaha mencapai keseimbangan antara relevansi dan keandalan, kebutuhan pengambilan keputusan merupakan pertimbangan yang menentukan (IAI, 2004). Oleh karena itu pelaporan tepat waktu merupakan aspek yang penting untuk diperhatikan oleh para perusahaan emiten karena jika melaporkan tidak tepat waktu akan mengurangi relevansi dan nilai keandalan dari informasi yang disajikan. Banyak pihak percaya bahwa ketepatan waktu pelaporan keuangan (timelines) merupakan karakteristik penting bagi laporan keuangan, pihak-pihak tersebut antara lain akuntan, manajer dan analis keuangan karena berhubungan dengan proses pembuatan keputusan bisnis mereka. Bahkan Asosiasi Profesi Akuntansi pada tahun 1954 telah melakukan penelitian yang menyimpulkan bahwa ketepatan waktu pelaporan keuangan merupakan elemen pokok bagi catatan laporan keuangan yang memadai (Dyer dan Mchugh, 1975; 204).

Ketidaktepatan pelaporan keuangan juga bisa berakibat buruk bagi perusahaan emiten baik langsung maupun tidak langsung. Secara tidak langsung para investor mungkin menanggapinya sebagai pertanda (signal) yang buruk bagi perusahaan, karena informasi yang usang kurang bermanfaat dalam proses pembuatan keputusan investasi mereka. Secara langsung, sebagai contoh di pasar modal Australia pada tahun 1974 pernah 
terjadi 38 perusahaan delisting yakni sahamnya dilarang diperdagangkan hanya karena gagal memberikan laporan keuangan tahunan sesuai dengan persyaratan ketepatan waktu bagi bursa (Dyer dan Mchugh, 1975:205). Penelitian empiris juga telah menunjukkan bahwa ketepatan waktu pelaporan tahunan mempengaruhi harga sekuritas di pasar modal (Givoly dan Palmon, 1982).

Penelitian ini bukanlah meneliti pengaruh ketepatan waktu informasi yang dikeluarkan terhadap harga sekuritas yang diperdagangkan di pasar modal, tetapi ketepatan waktu pelaporan keuangan dan faktorfaktor yang mempengaruhinya karena bagi investor pelaporan tepat waktu akan membantu proses pengambilan keputusan. Pada kenyataannya dari hasil penelitian empiris beberapa peneliti sebelumnya tampaknya belum ada analisis sistematis terhadap faktor-faktor yang spesifik terkait dengan perusahaan, yang mempengaruhi ketepatan waktu pelaporan keuangan.

Penyempurnaan peraturan ini dimaksudkan agar investor dapat lebih cepat memperoleh informasi keuangan sebagai dasar dalam pengambilan keputusan investasi serta menyesuaikan dengan perkembangan pasar modal. Sehubungan dengan kewajiban penyampaian laporan keuangan, Bapepem juga mengatur tentang sanksi bagi perusahaan yang tidak tepat waktu dalam menyampaikan laporan keuangan ke Bapepam. Jika perusahaan telat menyampaikan laporan keuangan sampai 30 hari kalender terhitung sejak batas akhir seharusnya, maka BEI akan menjatuhkan sanksi tertulis I. Nantinya, jika pada hari kalender ke-31 hingga ke-60 belum juga menyampaikan, maka sanksi tertulis II akan melayang. Sanksi ini disertai dengan denda sebesar Rp 50 juta. Selanjutnya, jika pada hari kalender ke-61 hingga ke-90, perseroan masih membandel, maka bursa akan memberi peringatan tertulis III plus denda Rp 150 juta.

Laporan keuangan sebagai bentuk pertanggungjawaban manajemen kepada pemilik saham dan juga bagi pengambilan keputusan. Laporan keuangan yang disampaikan kepada Badan Pengawas Pasar Modal (Bappepam) merupakan laporan keuangan yang telah diaudit oleh akuntan publik yang bersertifikat dan disertai opini (pendapat) auditLaporan keuangan harus memenuhi empat karakteristik kualitatif yang merupakan ciri khas yang membuat informasi laporan keuangan berguna bagi pemakainya. Keempat karekteristik tersebut yaitu dapat dipahami, relevan, handal dan dapat diperbandingkan. Informasi yang relevan akan bermanfaat bagi para pemakainya jika disampaikan dengan tepat waktu guna pengambilan keputusan. Apabila informasi tidak disampaikan dengan 
tepat waktu akan menyebabkan kehilangan nilai didalam mempengaruhi kualitas keputusan (IAI, 2009).

Mengingat pentingnya informasi perusahaan maka ketepatan waktu pelaporan memegang peranan yang tinggi bagi pihak yang membutuhkan. Tepat waktu berarti informasi keuangan tersebut dapat digunakan oleh pemakainya dalam mengambil keputusan. Penelitian ini dilakukan pada perusahaan tambang yang terdaftar di Bursa Efek Indonesia dengan tahun sampel 2016 sampai dengan 2018. Rasio keuangan dalam penelitian ini menggunakan Profitabilitas (ROA), Kesulitan Keuangan (DER), Ukuran Perusahaan (SIZE) dan Umur Perusahaan (AGE). Hasil penelitian Agrianti (2003) menunjukkan Profitabilitas (ROA), Kesulitan Keuangan (DER) berpengaruh tidak signifikan terhadap ketepatan waktu pelaporan sedangkan hasil penelitian Owusu \& Ansah (2000) Profitabilitas (ROA, Ukuran Perusahaan (SIZE) berpengaruh signifikan terhadap ketepatan waktu penyampaian laporan keuangan.

Ifada (2009) melakukan penelitian mengenai faktor-faktor yang mempengaruhi ketepatan waktu pelaporan keuangan studi kasus perusahaan manufaktur yang terdaftar di Bursa Efek Indonesia. Rasio keuangan dalam penelitian ini menggunakan Ukuran Perusahaan, Insider Ownership (INSIDER), Debt Equity Rasio (DER), Return On Asset (ROA), outsider ownership (OUTSIDER), dan Umur Perusahaan (AGE). Dari hasil penelitian yang dilakukan, maka dapat menarik kesimpulan sebagai berikut : Variabel ukuran perusahaan (SIZE) dan Insider Ownership (INSIDER) secara signifikan berpengaruh terhadap ketepatan waktu pelaporan keuangan perusahaan-perusahaan manufaktur. Sedangkan DER,ROA, OUTSIDER, dan AGE secara signifikan tidak berpengaruh terhadap ketepatan waktu pelaporan keuangan perusahaan manufaktur.

Marathani melakukan penelitian tentang faktor-faktor yang mempengaruhi ketepatan waktu penyampaian laporan keuangan studi empiris pada perusahaan manufaktur yang terdaftar di Bursa Efek Indonesia tahun 2010-2012. Variabel yang dilakukan dalam penelitian ini adalah profitabilitas,likuiditas, leverage, opini audit, kualitas auditor dan ukuran perusahaan. Berdasarkan hasil penelitian ini maka dapat disimpulkan bahwa faktor-faktor yang dapat mempengaruhi ketepatan waktu penyampaian laporan keuangan pada perusahaan manufaktur adalah profitabilitas, likuiditas, leverage dan ukuran perusahaan. Penelitian ini tidak berhasil menemukan bukti adanya pengaruh antara opini audit dan kualitas auditor terhadap ketepatan waktu penyampaian laporan keuangan. 
hal ini membuktikan bahwa perusahaan akan segera menyampaikan laporan keuangannya segera mungkin dengan memperhatkan faktor-faktor yang dapat mempengaruhi tersebut.

Dari beberapa penelitian sebelumnya penulis ingin melakukan replikasi penelitian dengan menggunakan rasio-rasio keuangan yakni rasio profitabilitas dijelaskan dengan Return on Asset (ROA), rasio leverages dijelaskan dengan Debt to Equity Ratio (DER), Ukuran perusahaan (SIZE) dan Umur Perusahaan.

\section{TELAAH TEORI}

\section{Teori Ketaatan}

Menurut Suryandini (2008) dalam Dwiyanti (2010) seorang individu cenderung mematuhi hukum yang mereka anggap sesuai dan konsisten dengan norma-norma internal mereka. Komitmen normatif melalui moralitas personal (normative commitment through morality) berarti mematuhi hukum karena hukum tersebut dianggap sebagi suatu keharusan, sedangkan komitmen normative melalui legistemasi (normative commitment throughlegitimary) berarti mematuhi peraturan karena otoritas penyusun hukum tersebut memiliki hak untuk mendikte perilaku.

Tuntutan akan kepatuhan terhadap ketepatan waktu dalam UndangUndang Tahun 1995 tentang Pasar Modal, dan selanjutnya diatur dalam peraturan Bappepam tentang Kewajiban Penyampaian Laporan Keuangan Berkala. Peraturan - peraturan tersebut secara hukum mengisyrakatkan adanya kepatuhan setiap perilaku individu maupun organisasi (perusahaan publik) yang terlibat di pasar modal Indonesia untuk menyampaikan laporan keuangan tahunan perusahaan secara tepat waktu kepada Bappepam. Perusahaan yang terlambat menyampaikan laporan keuangan akan dikenakan denda berdasarkan ketentuan pasal 63 huruf e Peraturan Pemerintah Nomor 45 tahun 1995 tentang Penyelenggaraan Kegiatan di bidang Pasar Modal yang menyatakan bahwa "Emitmen yang pernyataan pendaftaraanya telah menjadi efektif, dikenakan sanksi denda Rp.1.000.000 (satu juta rupiah) atas setiap hari keterlambatan penyampaian laporan keuangan dengan ketentuan jumlah keseluruhan denda paling banyak Rp.500.000.000 (lima ratus juta rupiah)" (www.bappepam.go.id). Peraturan tersebut sesuai dengan teori kepatuhan. 


\section{Ketepatan Waktu Pelaporan Keuangan (Timeliness)}

Menurut (IAI, 2009) tujuan laporan keuangan adalah memberikan informasi mengenai posisi keuangan, kinerja keuangan, dan arus kas entitas yang bermanfaat bagi sebagian besar kalangan pengguna laporan dalam pembuatan keputusan ekonomi. Salah satu karakteristik kualitatif laporan keuangan adalah relevan. Relevan artinya bahwa informasi tersebut dapat membantu para pengguna laporan keuangan dalam membuat keputusan ekonomi. Pembuatan keputusan ekonomi dilakukan dengan mengevaluasi peristiwa yang terjadi dimasa lalu. Salah satu indikator dari relevansi itu adalah ketepatan waktu (timeliness). Ketepatan waktu adalah informasi yang ada siap untuk digunakan sebelum kehilangan makna oleh pemakai laporan keuangan serta kapasitasnya masih tersedia dalam pengambilan keputusan.

Menurut Hendriksen dan Bradea (2000) dalam Dwianty (2010) Ketepatan waktu merupakan batasan penting dalam publikasi laporan keuangan. Akumulasi, peringkasan, dan penyajian selanjunya informasi akuntansi dilakukan secepat mungkin untuk menjamin tersedianya informasi sekarang ditangan pemakai. Ketepatan waktu juga menunjukkan bahwa laporan keuangan harus disajikan pada kurun waktu teratur untuk memperlihatkan perubahan keadaan perusahaan pada gilirannya mungkin akan mempengaruhi prediksi dan keputusan pemakai.

Menurut Kartika (2009) manfaat dari laporan keuangan suatu perusahaan tergantung pada keakuratannya dan ketepatan waktunya. Informasi yang relevan akan bermanfaat bagi para pemakai apabila tersedia tepat waktu sebelum pemakai kehilangan kesempatan atau kemampuan untuk memepengaruhi keputusan yang diambil. Dalam melaksanakan audit, maka dibutuhkan sebuah perencanaan. Perencanaan audit termasuk juga membuat anggaran waktu (time budget) yaitu menetapkan pedoman mengenai jumlah waktu dari masing-masing bagian audit. Anggaran waktu merupakan suatu pedoman. Apabila auditor menyimpang dari program audit akibat suatu kondisi , auditor juga mungkin terpaksa menyimpang dari anggaran waktu. Auditor mendapat tekanan dalam memenuhi anggaran waktu untuk menunjukkan efesiensinya dan membantu mengevaluasi kinerjanya. Akan tetapi, bila tidak sesuai dengan tujuan pokok audit, maka informasi yang disampaikan juga tidak baik dan dapat merugikan. Hal ini berpengaruh terhadap para pengambil keputusan. Apabila informasi yang disampaikan tidak sesuai maka penyampaian laporan keuangan ke Bappepam akan ditunda. 


\section{Profitabilitas}

Menurut Kasmir (2012:196) Profitabilitas adalah rasio untuk menilai kemampuan perusahaan dalam mencari keuntungan. Perusahaan yang memiliki profitabilitas tinggi dapat dikatakan bahwa laporan keuangan perusahaan tersebut mengandung berita baik dan perusahaan yang mengalami berita baik akan cenderung menyerahkan laporan keuangannya tepat waktu. Return On Asset merupakan rasio yang menunjukkan berapa besar laba bersih diperoleh perusahaan bila diukur dari nilai aktiva.

\section{Kesulitan Keuangan (DER)}

Menurut Kasmir (2012: 112) Rasio leverage merupakan rasio yang digunakan untuk mengukur sejauh mana aktiva perusahaan dibiayai dengan utang. Artinya, berapa besar beban utang yang ditanggung perusahaan dibandingkan dengan asetnya. . Dalam arti luas dikatakan bahwa rasio leverage digunakan untuk mengukur kemampuan perusahaan untuk membayar seluruh kewajiban baik jangka pendek maupun jangka panjang apabila perusahaan dibubarkan (dilikuidasi).

Kesulitan keuangan dalam penelitian ini diproksi dengan rasio leverage dengan menggunakan Debt to Equity Ratio (DER). Debt to equty ratio $(D E R)$ merupakan rasio yang digunakan untuk menilai utang dengan ekuitas. Untuk mencari rasio ini dengan cara membandingkan antara seluruh utang, termasuk utang lancar dengan seluruh ekuitas. Rasio ini berguna untuk mengetahui jumlah dana disediakan peminjam (kreditor) dengan pemilik perusahaan. Dengan kata lain rasio ini untuk mengetahui setiap rupiah modal sendiri yang dijadikan jaminan utang (Kasmir, 2012).

\section{Ukuran Perusahaan (SIZE)}

Menurut Hilmi dan Ali (2008) dalam Agus (2010) ukuran perusahaan dapat dinilai dari beberapa aspek. Besar kecilnya ukuran perusahaan dapat didasarkan pada total nilai aktiva, total penjualan, kapitalisasi pasar, jumlah tenaga kerja, dan sebagainya. Perusahaaan yang memiliki sumber daya (asset) yang besar meliliki lebih banyak sumber informasi, sistem informasi yang lebih canggih, memiliki sistem pengendalian intern yang kuat, adanya pengawasan dari investor dan sorotan masyarakat maka hal ini memungkinkan perusahaan untuk melaporkan laporan keuangan auditnya lebih cepat ke publik. Informasi yang terkandung dalam perusahaan besar sangat diperhatikan masyarakat. 
Semakin besar suatu perusahaan maka semakin banyak pihak - pihak yang berkepentingan didalam perusahaan itu.

\section{Umur Perusahaan (AGE)}

Ketepatan waktu pelaporan keuangan sebuah perusahaan dipengaruhi oleh umur perkembangan maupun pertumbuhannnya (Owusu dan Ansah,2000). Pernyataan ini didasarkan pada teori kurva pembelajaran (learning curve).Perusahaan yang telah lama terdaftar di bursa efek, membuat para akuntannya lebih jeli mengamati hal-hal yang mengakibatkan penundaan penyampaian laporan tahunannya ke Bursa Efek. Oleh karena itu perusahaan akan lebih efisien memanfaatkan waktu dalam mengumpulan, memproses dan mempublikasi informasi ketika dibutuhkan karena lebih berpengalaman. Maka umur perusahaan diukur dari lamanya perusahaan telah terdaftar di Bursa Efek.

\section{Pengaruh Profitabilitas terhadap ketepatan waktu pelaporan keuangan}

Menurut Kasmir (2012:196) Profitabilitas adalah rasio untuk menilai kemampuan perusahaan dalam mencari keuntungan. Rasio ini juga memberikan ukuran tingkat efektivitas manajemen suatu perusahaan. perusahaan yang memiliki profitabilitas tinggi dapat dikatakan bahwa laporan keuangan perusahaan tersebut mengandung berita baik dan perusahaan yang mengalami berita baik akan cenderung menyerahkan laporan keuangannya tepat waktu. Hal ini juga berlaku jika profitabilitas perusahaan rendah dimana hal ini mengandung berita buruk, sehingga perusahaan cenderung tidak tepat waktu menyerahkan laporan keuangann Return On Asset merupakan rasio yang menunjukkan berapa besar laba bersih diperoleh perusahaan bila diukur dari nilai aktiva.

\section{Pengaruh Debt to Equity Ratio terhadap ketepatan waktu pelaporan keuangan}

Menurut Kasmir (2012:151) rasio leverage adalah rasio yang digunakan untuk mengukur sejauh mana aktivitas perusahaan dibiayai oleh hutang. Penggunaan hutang yang terlalu tinggi akan membahayakan perusahaan karena perusahaan akan masuk kategori hutang ekstrem yaitu perusahaan terjebak dalam tingkat hutang yang tinggi dan sulit untuk melepaskan beban hutang tersebut. Rasio ini dapat diukur dengan debt to equity ratio. Tingginya leverage keuangan mencerminkan tingginya risiko keuangan perusahaan. Risiko keuangan yang tinggi mengindikasikan 
bahwa perusahaan mengalami kesulitan keuangan. Kesulitan keuangan perusahaan merupakan berita buruk yang akan mempengaruhi kondisi perusahaan di mata publik. Oleh karena itu, semakin tinggi rasio debt to equity suatu perusahaan maka perusahaan tersebut cenderung tidak tepat waktu dalam menyampaikan laporan keuangan.

\section{Pengaruh Ukuran Perusahaan dengan ketepatan waktu pelaporan keuangan}

Menurut Permatasari (2012:112) Ukuran perusahaan merupakan gambaran besar kecilnya peusahaan yang ditentukan berdasarkan sebuah ukuran yang dapat dinilai. Besar kecilnya ukuran perusahaan dapat dilihat dari total aktiva, total penjualan dan juga dipengaruhi oleh operasional dan intensitas perusahaan. Semakin besar nilai asset perusahaan, maka akan semakin cepat penyampaian laporan keuangan auditan dan sebaliknya.Pada dasarnya ukuranperusahaan hanya terbagi dalam 3 kategori, yaitu: perusahaan besar (large firm), perusahaan sedang (medium firm), dan perusahaan kecil (small firm). Ukuran perusahaan dalam penelitian ini diukur dengan melihat total aset yang dimiliki oleh perusahaan. Perusahaan yang memiliki total aktiva besar menunjukkan bahwa perusahaan tersebut telah mencapai tahap kedewasaan dimana dalam tahap ini arus kas perusahaan sudah positif dan dianggap memiliki prospek yang baik dalam jangka waktu yang relatif lama.

\section{Pengaruh Umur Perusahaanterhadap ketepatan waktu pelaporan keuangan}

Ketepatan waktu pelaporan keungan sebuah perusahaan dipengaruhi oleh umur perkembangan maupun pertumbuhannnya (Owusu dan Ansah,2000). Pernyataan ini didasarkan pada teori kurva pembelajaran (learning curve).Perusahaan yang telah lama terdaftar di bursa efek, membuat para akuntannya lebih jeli mengamati hal-hal yang mengakibatkan penundaan penyampaian laporan tahunannya ke Bursa Efek. Oleh karena itu perusahaan akan lebih efisien memanfaatkan waktu dalam mengumpulan, memproses dan mempublikasi informasi ketika dibutuhkan karena lebih berpengalaman sehingga penundaaan pelaporan akan diminimalisir. Oleh karena itu boleh jadi umur mempengaruhi ketepatan waktu penyampaian laporan tahunan sehingga dapat dinyatakan makin tinggi umur perusahaan boleh jadi akan meningkatkan ketepatan waktu penyampaian laporan tahunan emiten 


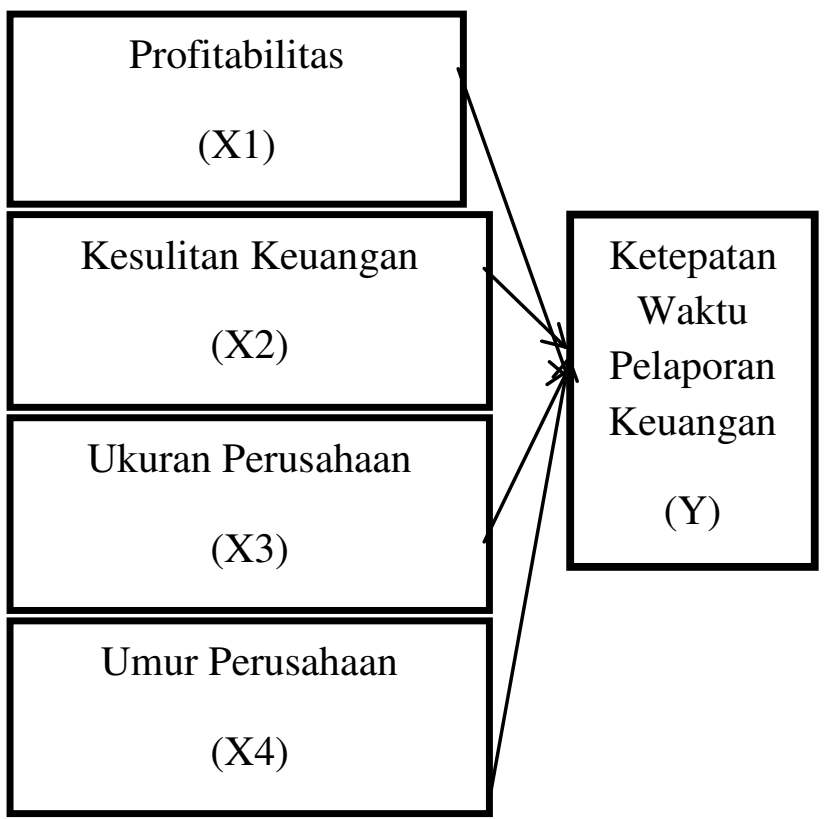

\section{Hipotesis}

Hipotesis dirumuskan sebagai berikut :

H1 : Return On Asset berpengaruh positif terhadap ketepatan waktu penyampaian laporan keuangan

H2 : Debt to Equity Ratio berpengaruh negatif terhadap ketepatan waktu penyampaian laporan keuangan

H3 : Ukuran perusahaan berpengaruh positif terhadap ketepatan waktu pelaporankeuangan.

H4 : Umur perusahaan berpengaruh positif terhadap ketepatan waktu pelaporan keuangan.

\section{METODOLOGI PENELITIAN}

\section{Populasi dan Sampel}

Populasi dalam penelitian ini adalah perusahaan tambang yang terdaftar di Bursa Efek Indonesia periode 2016-2018. Sesuai dengan pengklasifikasian Indonesian Capital Market Directory tahun 2016-2018. Sampel penelitian adalah 17 perusahaan, pengamatan yang dijadikan sampel adalah sebanyak 33 tahun sehingga jumlah sampel (17 x 3 tahun) $=51$ pengamatan . 


\section{Definisi Operasional dan Pengukuran Variabel}

a. ketepatan waktu pelaporan keuangan. Perusahaan dikatakan tepat waktu apabila perusahaan tersebut menyampaikan laporan keuangan sebelum tanggal jatuh tempo yang ditetapkan oleh Bapepam, yakni kurang atau sama dengan 90 hari dari tanggal tutup buku. Tanggal tutup buku adalah 31 Desember.Perusahaan tidak tepat waktu apabila perusahaan tersebut terlambat menyampaikan laporan keuangnnya setelah batas waktu yang ditetapkan oleh Bapepam.Dalam model regresi, perusahaan tepat waktu diberi kode 1 dan tidak tepat waktu diberi kode 0.Skala pengukurannya adalah skala nominal.

b. Profitabilitas yang diproksi dengan Return On asset (ROA)merupakan rasio antara Net Income After Tax terhadap Asset secara keseluruhan yang menunjukkan ukuran produktivitas aktiva dalam memberikan pengembalian kepada investor (Meythi 2005).

c. Kesulitan Keuangan yang diproksi denganDebt to Equity Ratio (DER) Rasio ini mengukur tingkat penggunaan hutang terhadap total shareholders equity yangdimiliki perusahaan.(Saleh, 2003).

d. Ukuran Perusahaan (SIZE) ditunjukkan oleh total Asset akhir tahun masing-masing emiten selama tiga tahun pengamatan.

e. Umur Perusahaan (AGE), ukuran yang digunakan dalam penelitian ini adalah lamanya (jumlah tahun) yakni dari tahun dimana perusahaan mulai mempublikasikan laporan tahunannya.

\section{Teknik Pengumpulan Data}

Teknik dokumentasi yang diperoleh dari Bursa Efek Indonesia. Data yang digunakan dalam penelitian ini adalah data sekunder, yakni adalah Profitabilitas, Kesulitan Keuangan, Ukuran Perusahaan, Umur Perusahaandan Ketepatan Waktu Pelaporan Keuangan di Indonesia Periode 2016-2018.

\section{Model Penelitian}

Data dalam penelitian ini dianalisis dengan menggunakan regresi logistik.

Persamaan regresi dalam penelitian ini adalah:

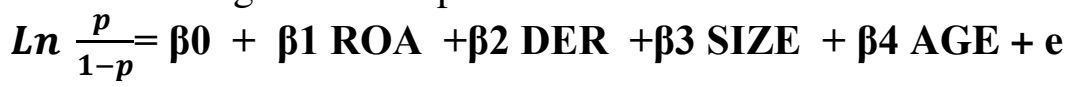

Keterangan :

$$
\begin{array}{lll}
\operatorname{Ln} \frac{\boldsymbol{p}}{\mathbf{1 - p}} & \text { : } & \text { simbol yang menunjukkan probabilitas ketepatan waktu } \\
& \text { penyampaian laporan keuangan (kategori } 0 \text { untuk }
\end{array}
$$


perusahaan yang tidak tepat waktu dan kategori 1 yang tepat waktu ) dimana $\mathrm{p}=$ probabilitas tepat waktu, 1-p=

及0 : Konstanta probabilitas tidak tepat waktu.

$\boldsymbol{\beta 1}, \boldsymbol{\beta 2}, \boldsymbol{\beta 3}, \boldsymbol{\beta 4}$ : Koefisien Regresi

ROA : Return On Asset (Profitabilitas)

DER : Debt to Equity Ratio (Leverage)

SIZE : Ukuran Perusahaan

AGE : Umur Perusahaan

e : Variabel gangguan

\section{Teknik Analisis}

Data penelitian dianalisis dengan alat statistik, yang terdiri atas:

\section{a. Statistik Deskriptif}

Statistik deskriptif digunakan untuk mendeskripsikan variablevariabel yang ada dalam penelitian ini yakni Return On Asset, Debt To Equity Ratio, Ukuran Perusahaan (SIZE) dan Umur perusahaan (AGE). Alat analisis yang digunakan adalah nilai minimum, nilai maksimum, rata - rata (mean) dan standar deviasi.

\section{b. Uji Hipotesis}

Pengujian hipotesis dilakukan secara uji multivariate dengan menggunakan regresi logistik. Regresi logistik digunakan karena variabel dependennya berupa non- metric yaitu kategori 1 dan 0 . Tujuan regresi logistic untuk memperkirakan besarnya probabilitas kejadian tertentu. Regresi logistic menguji apakah probabilitas terjadinya variabel terikat diprediksi variabel bebasnya. Analisis pengujian dengan regresi logistic menurut Ghozali (2005) memperhatikan hal - hal sebagai berikut :

\section{c. Menilai Kelayakan Model Regresi}

Menurut Ghozali (2005) Analisis pertama yang dilakukan adalah menilai kelayakan model regresilogistic yang digunakan. Pengujian kelayakan model regresi logistic dilakukan dengan menggunakan:

- Goodness of fit test

- Menilai tabel klasifikasi,

a. Penilaian Keseluruhan Model (Overall Model Fit)

- Perbandingan Nilai -2Loglikehood

- Koefisien Determinasi Nagelkerke R square

b. Menguji Koefisien Regresi 


\section{HASIL PENELITIAN}

\section{Menilai Kelayakan Model Regresi}

Langkah pertama yang dilakukan adalah menilai kelayakan model regresi.Model regresi dikatakan mampu memperediksi nilai observasi dengan menggunakan nilai Hosmer and Lemeshow Goodness of Fit. Jika nilai statistik Hosmer and Lemeshow Goodness of Fit sama dengan atau lebih kecil dari 0.05, maka hipotesis nol (H0) ditolak dan hal tersebut berarti terdapat perbedaan signifikan antara model dengan nilai observasinya, sehingga model dikatakan tidak baik karena model tidak dapat memprediksi nilai observasinya. Sebaliknya, jika nilai statistiknya lebih besar dari 0.05, maka hipotesis nol (H0) diterima dan hal tersebutterbukti bahwa model mampu memprediksi nilai observasinya.

Hasil dari penilaian kelayakan model regresi tersebut dapat dilihat pada Tabel 1 berikut :

Tabel 1

Hosmer and Lemeshow Test

\begin{tabular}{|l|l|l|l|}
\hline Step & Chi-square & df & Sig. \\
\hline 1 & 7.398 & 8 & .494 \\
\hline
\end{tabular}

Dapat dilihat pada Tabel 1 bahwa besarnya nilai statistik Hosmer and Lemeshow Goodness-of-Fit sebesar 7.398 dengan nilai probabilitas signifikansi 0.494 yang berarti lebih besar dari 0.05. Sehingga dapat diketahui bahwa $\mathrm{H} 0$ diterima dan dapat disimpulkan bahwa model regresi logistik yang digunakan telah sesuai dan model regresi layak digunakan untuk analisa selanjutnya.

\section{Menilai Keseluruhan Model}

Dalam regresi logisitik, hasil selisih statistik -2log-likelihood antaramodel regresi logistik yang menggunakan satu set variabel bebas dan model yang lebih sederhana (simpler model) dapat digunakan untuk mengetahui apakah model regresi logistik yang menggunakan satu set variabel bebas lebih baik dalam hal mencocokkan atau menyesuaikan data dibandingkan model regresi logistik yang sederhana. Jika statistik -2loglikelihood pada model regresi logistik yang menggunakan satu set variabel bebas lebih kecil dibandingkan model yang lebih sederhana, maka model regresi logistik yang menggunakan satu set variabel bebas lebih baik dalam hal mencocokkan data dibandingkan model yang lebih sederhana tersebut. (Sianturi,2018). 
Tabel 2

Blok 0 Nilai -2 Log likelihood (-2 LL Awal)

Iteration History $\mathbf{y}^{\mathrm{a}, \mathrm{b}, \mathrm{c}}$

\begin{tabular}{|cr|c|c|}
\hline \multicolumn{2}{|c|}{ Iteration } & \multirow{2}{*}{$\begin{array}{c}-2 \text { Log } \\
\text { likelihood }\end{array}$} & Coefficients \\
\cline { 4 - 4 } Step 0 & 1 & 48.006 & Constant \\
\hline & 2 & 47.534 & 1.294 \\
& 3 & 47.532 & 1.523 \\
& 4 & 47.532 & 1.540 \\
\hline
\end{tabular}

Tabel 3

Blok 0 Nilai -2 Log likelihood (-2 LL Akhir) Iteration History $\mathbf{a}, \mathbf{b}, \mathbf{c}, \mathbf{d}$

\begin{tabular}{|r|c|c|c|c|c|c|}
\hline \multirow{2}{*}{$\begin{array}{c}\text { Iteratio } \\
\mathrm{n}\end{array}$} & \multirow{2}{*}{$\begin{array}{c}-2 \text { Log } \\
\text { likelihood }\end{array}$} & \multicolumn{6}{|c|}{ Coefficients } \\
\cline { 3 - 7 } Step 1 1 & Constant & Profitabilitas & $\begin{array}{c}\text { Kesulitan } \\
\text { Keuangan }\end{array}$ & $\begin{array}{c}\text { Ukuran } \\
\text { Perusahaan }\end{array}$ & $\begin{array}{c}\text { Umur } \\
\text { Perusahaan }\end{array}$ \\
\hline 2 & 38.814 & 2.678 & 1.053 & -.185 & -.048 & -.020 \\
3 & 35.389 & 3.523 & 2.952 & -.338 & -.055 & -.032 \\
4 & 33.186 & 3.165 & 4.799 & -.541 & .000 & -.036 \\
5 & 33.842 & 2.553 & 5.237 & -.739 & .075 & -.039 \\
6 & 33.842 & 2.409 & 5.320 & -.776 & .093 & -.040 \\
7 & 33.842 & 2.406 & 5.325 & -.776 & .093 & -.040 \\
& & 5.325 & -.776 & .093 & -.040 \\
\hline
\end{tabular}

Berdasarkan Tabel 3, nilai -2Log Likelihood akhir pada Step IIteration 7 adalah 33,842 <-2Log Likelihood awal pada Step 0 Iteration 2 sebesar 47,532. Adanya penurunan nilai antara -2Log Likelihood awaldengan nilai -2Log Likelihood akhir menunjukkan model penelitian inidinyatakan fit, artinya penambahan-penambahan variabel bebas yaituprofitabilitas, kesulitan keuangan, ukuran perusahaan dan umur perusahaan terhadap ketepatan waktu pelaporan keuangan ke dalam model penelitianakan memperbaiki model fit dalam penelitian ini.

\section{Koefisien Determinasi (Cox dan Snell's R square)}

Dalam regresi logistik, dapat digunakan statistik Nagelkerke's untuk mengukur kemampuan model regresi logistik dalam mencocokkan atau menyesuaikan data. Dengan kata lain, nilai statistik dari Nagelkerke's dapat diinterpretasikan sebagai suatu nilai yang mengukur kemampuan 
variabel-variabel independen dalam menjelaskan atau menerangkan variabel dependen. Tabel 5.4 menyajikan nilai statistik dari Nagelkerke's.

Tabel 4

Nagelkerke $R$ Square

Model Summary

\begin{tabular}{|l|l|lr|l|}
\hline Step & $\begin{array}{l}\text { - Log } \\
\text { likelihood }\end{array}$ & $\begin{array}{l}\text { \&ox } \\
\text { Snell } \\
\text { Square }\end{array}$ & $\begin{array}{l}\text { Nagelkerke } \\
\text { R Square }\end{array}$ \\
\hline 1 & $33.842^{\mathrm{a}}$ & .235 & .388 \\
\hline
\end{tabular}

a. Estimation terminated at iteration number

7 because parameter estimates changed by less than .001.

Berdasarkan Tabel 4 dapat dilihat bahwa nilai statistic Nagelkerke $R$ Square 0,388 atau $38,8 \%$ yang artinya nilai tersebut diinterpretasikan sebagai kemampuan variabel profitabilitas, kesulitan keuangan, ukuran perusahaan dan umur perusahaan terhadap ketepatan waktu pelaporan keuangan sebesar 38,8 \% dan sisanya $61,2 \%$ dijelaskan oleh variabelvariabel atau faktor-faktor lain di luar model penelitian.

\section{Uji Koefisien Regresi}

Pada regresi logistik, pengujian secara parsial ditunjukkan pada variables in the equation yang bertujuan untuk mengetahui signifikan konstanta dari setiap variabel independen yang masuk ke dalam model.

\section{Tabel 5}

\section{Hasil Uji Koefisien Regresi}

Variables in the Equation

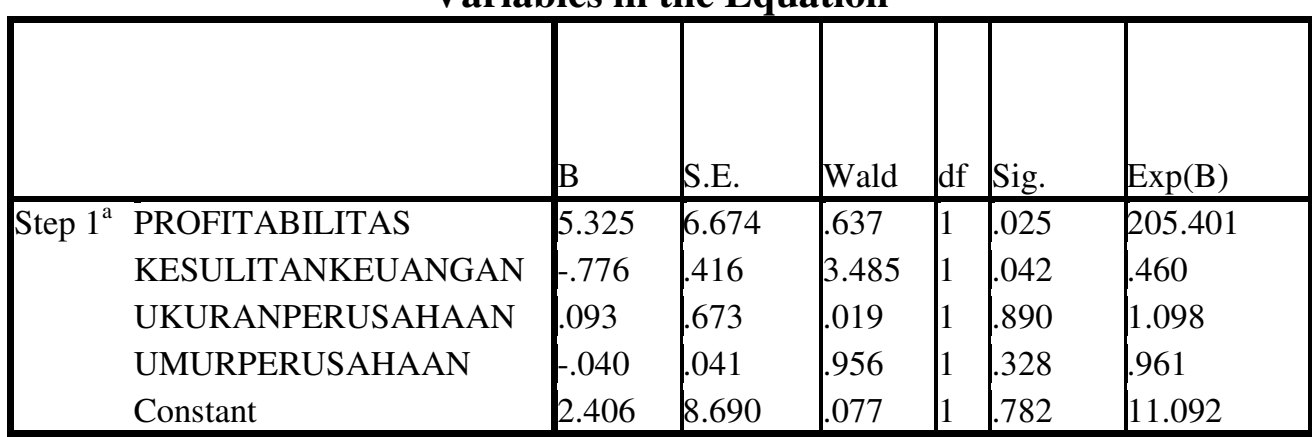

Berdasarkan tabel 5 persamaan model analisis regresi logistik dalam peneltian ini adalah sebagai berikut :

$\mathrm{Y}=2,406+5,325 \mathrm{X} 1-0.776 \mathrm{X} 2+0.093 \mathrm{X} 3-0,040 \mathrm{X} 4+\mathrm{e}$ 
Dari persamaan regresi logistik di atas dapat dijelaskan :

1. Konstanta sebesar 2,406 mengindikasikan bahwa jika semua variabel bebas penelitian bernilai nol, maka ketepatan waktu pelaporan keuangan akan bernilai 2,406.

2. Kofisien regresi variabel profitabilitas sebesar 5,325 mengindikasikan bahwa apabila terjadi peningkatan profitabilitas sebesar 1 satuan sedangkan variabel lain dianggap konstan, maka akan menaikkan variabel ketepatan waktu pelaporan keuangan sebesar 5,325.

3. Kofisien regresi variabel kesulitan keuangan sebesar $-0,776$ mengindikasikan bahwa apabila terjadi peningkatan kesulitan keuangan sebesar 1 satuan sedangkan variabel lain dianggap konstan, maka akanmenurunkan variabel ketepatan waktu pelaporan keuangan sebesar $-0,776$.

4. Kofisien regresi variabel ukuran perusahaan sebesar 0,093 mengindikasikan bahwa apabila terjadi peningkatan ukuran perusahaan sebesar 1 satuan sedangkan variabel lain dianggap konstan, maka akan menaikkan variabel ketepatan waktu pelaporan keuangan sebesar 0,093.

5. Kofisien regresi variabel umur perusahaan sebesar $-0,040$ mengindikasikan bahwa apabila terjadi peningkatan umur perusahaan sebesar 1 satuan sedangkan variabel lain dianggap konstan, maka akan menurunkan variabel ketepatan waktu pelaporan keuangan sebesar -0,216.

\section{Pengujian Hipotesis Penelitian}

\section{a. Uji Omnibus Tests of Model Coefficients}

Pada regresi logistik, hasil Omnibus Tests of Model Coefficient bertujuan untuk melihat apakah variabel independen secara bersamasamaberpengaruh terhadap variabel dependen dengan menggunakan nilai Chisquare (selisih antara -2 Log Likelihood awal dan -2 Log Likelihood selanjutnya). (Auwina,2019).

Untuk menguji apakah model regresi logistik yang melibatkan variabel bebas signifikan (secara simultan) lebih baik dibandingkan model sebelumnya (model sederhana) dalam hal mencocokkan data, maka bandingkan nilai Sig.pada Tabel Omnobus Tests of ModelCoefficients terhadap tingkat signifikansi 0,05. Nilai Sig. disebut juga dengan nilai probabilitas. 
1. Jika nilai probabilitas lebih kecil (Sig.) dari tingkat signifikansi, maka disimpulkan bahwa model yang melibatkan variabel bebas signifikan (secara simultan) lebih baik dalam hal mencocokkan data dibandingkan model sederhana.

2. Jika nilai probabilitas (Sig.) lebih besar dari tingkat signifikansi, maka disimpulkan bahwa model yang melibatkan variabel bebas tidak signifikan (secara simultan) lebih baik dalam hal mencocokkan data dibandingkan model sederhana.

\section{Tabel 6}

Hasil Omnibus Tests of Model Coefficients

\begin{tabular}{|ll|l|l|l|}
\hline & & Chi-square & df & Sig. \\
\hline Step 1 & Step & 13.690 & 4 & .008 \\
& Block & 13.690 & 4 & .008 \\
& Model & 13.690 & 4 & .008 \\
\hline
\end{tabular}

Pada tabel Omnibus Tests of Model Coefficients dapat dilihat nilai Chi-square, $d f$, dan signifikan omnibus. Nilai signifikan sebesar 0.008 dimana $0.008<0.05$. Sehingga dapat disimpulkan hipotesis untuk pengaruh simultan antara variabel independen terhadap variabel dependen adalah Ha diterima dan menolak Ho yang berarti ada pengaruh secara simultan antara profitabilitas, kesulitan keuangan, ukuran perusahaan dan umur perusahaan terhadap ketepatan waktu pelaporan keuangan.

\section{b. Uji Signifikansi Model Secara Parsial (Uji Wald)}

Berdasarkan Tabel 5, maka Uji Signifikansi nya secara Parsial adalah sebagai berikut :

1. Variabel Profitabilitas memiliki nilai signifikan 0.025 ,karena nilai sig. $0.025<0.05$, maka Ha diterima maka profitabilitas berpengaruh secara signifikan terhadap ketepatan waktu pelaporan keuangan .

2. Variabel Kesulitan Keuangan memiliki nilai signifikan 0.042, karena sig. $0.042<0.05$, maka Ha diterima maka Kesulitan Keuangan berpengaruh secara signifikan terhadap ketepatan waktu pelaporan keuangan.

3. Variabel Ukuran Perusahaan memiliki nilai signifikan 0.890, karena sig. $0.890>0.05$ maka Ha ditolak maka Ukuran Perusahaan 
tidak berpengaruh secara signifikan terhadap ketepatan waktu pelaporan keuangan.

4. Variabel Umur Perusahaan memiliki nilai signifikan 0.328, karena sig. $0.328>0.05$ maka Ha ditolak atau hipotesis maka Umur Perusahaan tidak berpengaruh secara signifikan terhadap ketepatan waktu pelaporan keuangan.

\section{Pengaruh Profitabilitas terhadap Ketepatan Waktu Penyampaian Laporan Keuangan}

Hasil uji signifikansi pada profitabilitas menunjukkan nilai probabilitas signifikansi sebesar $0,011(0,025<0,05)$. Nilai tersebut menunjukkan bahwa profitabilitas berpengaruh terhadap ketepatan waktu penyampaian laporan keuangan. Dengan kata lain menolak H0 atau menerima Ha sehingga "Profitabilitas berpengaruh terhadap ketepatan waktu penyampaian laporan keuangan"

Profitabilitas merupakan kemampuan perusahaan dalam menghasilkan laba.Semakin tinggi tingkat profitabilitas maka semakin tinggi kemampuan perusahaan dalam menghasilkan laba.Profitabilitas dapat mencerminkan keberhasilan suatu usaha sehingga dijadikan ukuran perusahaan tersebut mampu bejalan atau tidak. Perusahaan yang memiliki profitabilitas tinggi akan memiliki kabar baik dan perusahaan yang memiliki kabar baik akan cenderung menyampaikan laporan keuangannya tepat waktu.(Putri,2018). Hasil penelitian ini sesuai dengan penelitian yang dilakukan oleh Qomary et al. (2016) bahwa perusahaan yang memiliki tingkat profitabilitas tinggi akan lebih mengungkapkan laporan keuangan lebih tepat waktu karena hal tersebut merupakan berita baik. Hal ini sesuai dengan penelitian yang dilakukan oleh Issana Putri (2015) yang menghasilkan bahwa profitabilitas berpengaruh terhadap ketepatan waktu penyampaian laporan keuangan karena manajemen perusahaan yang mendapatkan keuntungan akan menggunakan informasi baik tersebut untuk memberikan sinyal kepada investor agar mendukung kelangsungan posisi manajemen saat ini dan kompensasi yang lebih tinggi pada manajemen.

\section{Pengaruh Kesulitan Keuangan terhadap Ketepatan Waktu Pelaporan Keuangan}

Berdasarkan uji Wald, kesulitan keuangan menunjukkan koefisien regresi negatif sebesar 0,776 dengan nilai probabilitas (Sig.) 0,042 yang 
lebih kecil dari 0,05, maka kesulitan keuangan berpengaruh terhadap ketepatan waktu pelaporan keuangan.

Hasil uji hipotesis ini sejalan dengan teori yang menyatakan perusahaan dengan leverage yang besar cenderung tepat waktu dalam penyampaian laporan keuangan. Perusahaan dengan nilai leverage yang tinggi atau rendah sama-sama memiliki kewajiban dalam menyampaikan laporan keuangan secara tepat waktu, hal ini dimaksudkan agar perusahaan tidak kehilangan kepercayaan dari publik maupun kreditur karena laporan keuangan sangat penting bagi pengambilan keputusan. (Dewayani, Amin dan Dewi, 2017).

\section{Pengaruh Ukuran Perusahaan terhadap Ketepatan Waktu Pelaporan Keuangan}

Berdasarkan uji Wald, Ukuran perusahaan menunjukkan koefisien regresi positif sebesar 0,093 dengan nilai probabilitas (Sig.) 0,890 yang lebih besar dari 0,05 , maka ukuran perusahaan tidak berpengaruh terhadap ketepatan waktu pelaporan keuangan.

Hasil uji hipotesis ini tidak sejalan dengan Almiliah dan Setiady (2006:04) dalam Nurmiati (2016) berpendapat bahwa ukuran perusahaan dapat menunjukan seberapa besar informasi yang terdapat didalamnya, sekaligus mencerminkan kesadaran dari pihak manajemen mengenai pentingnya informasi, baik bagi pihak eksternal perusahaan maupun pihak internal perusahaan. Perusahaan besar cenderung untuk menyajikan laporan keuangan lebih tepat waktu daripada perusahaan kecil.

\section{Pengaruh Umur perusahaan terhadap ketepatan waktu pelaporan keuangan}

Berdasarkan uji Wald, Umur perusahaan menunjukkan koefisien regresi negatif sebesar 0,040 dengan nilai probabilitas (Sig.) 0,328 yang lebih besar dari 0,05, maka umur perusahaan tidak berpengaruh terhadap ketepatan waktu pelaporan keuangan. Hasil ini sejalan dengan penelitian yang dilakukan oleh Astuti (2007) dan Setiawan dan Widyawati (2014) yang menunjukkan hasil umur perusahaan tidak berpengaruh terhadap ketepatan waktu pelaporan keuangan

\section{KESIMPULAN DAN SARAN}

\section{Kesimpulan}

a. Berdasarkan uji Omnibus Profitabilitas, Kesulitan Keuangan, Ukuran Perusahaan dan Umur Perusahaan menunjukkan nilai Sig. 
$0,008<0,05$, maka Profitabilitas, Kesulitan Keuangan, Ukuran Perusahaan dan Umur Perusahaan berpengaruh secara simultan terhadap terhadap Ketepatan Waktu Pelaporan Keuangan.

b. Berdasarkan uji Wald, variabel Profitabilias dan Kesulitan Keuangan berpengaruh secara signifikan terhadap Ketepatan Waktu Pelaporan Keuangan sedangkan variabel lain Ukuran Perusahaan dan Umur Perusahaan tidak berpengaruh secara signifikan terhadap Ketepatan Waktu Pelaporan Keuangan di Bursa Efek Indonesia.

c. Nilai statistik Nagelkerke $R$ Square 0,388 atau 38,8 \% yang artinya nilai tersebut diinterpretasikan sebagai kemampuan variabel profitabilitas, kesulitan keuangan, ukuran perusahaan dan umur perusahaan berpengaruh terhadap ketepatan waktu pelaporan keuangan sebesar 38,8\% dan sisanya 61,2\% dijelaskan oleh variabel-variabel atau faktor-faktor lain di luar model penelitian.

\section{Saran}

a. Karena variabel independen berkontribusi atau menjelaskan variabel ketepatan waktu penyampaian laporan keuangan hanya sebesar 38,8 $\%$ (sangat kecil), maka penelitian ini masih perlu dilanjutkan dengan cara menambah variabel-variabel independen lain yang memiliki kaitan erat dengan ketepatan waktu penyampaian laporan keuangan.

b. Untuk penelitian selanjutnya dapat menambah periode penelitian dan menambahkan periode yang terbaru agar dapat mencerminkan kondisi terkini dan dapat menambahkan sektor industri lain diluar sektor tambang agar lebih akurat hasil penelitiannya.

\section{DAFTAR PUSTAKA}

Agrianti,KSA.,2003, Faktor-Faktor Yang Menentukan Kepatuhan Perusahaan Publik Terhadap Regulasi Informasi di Indonesia, Tesis, Universitas Lampung.

Agus. 2010. Faktor - Faktor Yang Mempengaruhi Ketepatan Waktu Pelaporan Keuangan di Bursa Efek Indonesia. Universitas Syarif Hidayatullah.

Anggraini, Nafilah Ulfa.2018.Faktor-Faktor Yang Mempengaruhi Ketepatan Waktu Pelaporan Keuangan Pada Perusahaan Tambang Yang Terindeks di ISSI Tahun 2016-2017.INSTITUT AGAMA ISLAM NEGERI SURAKARTA 2018

Apostolou,Nick dan Nicholas, 2009, Memahami Laporan Keuangan dan Berita Keuangan, Gramedia Jakarta.

Astuti, Christina Dwi, 2007. "Faktor-Faktor yang berpengaruh terhadap ketepatan waktu pelaporan keuangan". Jurnal Informasi, Perpajakan, Akuntansi dan Keuangan Publik. Vol.2,No.1, Hlm. 27-42. 
Auwina, Dhea.2019. Pengaruh Struktur Kepemilikan, Ukuran Perusahaan dan Kualitas Auditor Terhadap Ketepatan Waktu Pelaporan Keuangan pada Perusahaan Manufaktur Sektor Industri Barang Konsumsi yang Terdaftar di BEI Tahun 2015-2017. Universitas Sumatera Utara, Medan.

Bandi dan Tri Hananto, Santoso, 2002, Ketepatan Waktu atas Laporan Keuangan Perusahaan Indonesia, Jurnal Bisnis dan Akuntansi, Vol.4.

Bapepam, 2002, Dalam Keputusan Bapepam: Kewajiban Penyampaiaan Laporan Keuangan Berkala. www.bapepam.go.id.

Dewayani, M.R., Amin dan Dewi. (2017). Analisis Faktor-Faktor Yang Mempengaruhi Ketepatan Waktu Pelaporan Keuangan (Study Empiris Pada Perusahaan Manufaktur Yang Terdaftar Di Bursa Efek Indonesia Periode 2011-2016). University Research Colloquium, 441-458.

Dyer, James C., Arthur J.McHugh, 1975, The Timelines Of The Australian Annual Report, Journal Of Accounting Research, Vol.13.

Ghozali, 2005. Aplikasi Analisis Multivrate Dengan Program IBM SPSS.Universitas Diponegoro, Semarang.

Harahap, Sofyan. 2004. Analisa Kritis Atas Laporan Keuangan. PT.Raja Grafindo Persada, Jakarta.

Hartati, Sri Nasution. 2016. Analisis Financial Distress Pada Sektor Pertambangan (Studi Kasus Pada Perusahaan Yang Terdaftar Di Bursa Efek Indonesia Periode 20112015). Universitas Islam Negeri Syarif Hidayatullah. Jakarta.

Herlyaminda dan Arfan, 2013. Pengaruh Financial Leverage, Likuiditas, Ukuran Perusahaan dan Umur Perusahaan terhadap KetepatanWaktuPenyampaian Laporan Keuangan pada perusahaan Real Estate dan Propertyyang terdaftar di Bursa Efek Indonesia. Jurnal Akuntansi Pascasarjana Universitas Syiah Kuala. Banda Aceh.

Issana Putri, A. (2015). Berbagai Faktor Yang Mempengaruhi Ketepatan Waktu Pelaporan Keuangan Apriliani Issana Putri.Jurnal Ilmu \& Riset Akuntansi, 4(7).

Ifada, 2009. Faktor-Faktor Yang Mempengaruhi Ketepatan Waktu Pelapo Keuangan Perusahaan Manufaktur di Bursa Efek Jakarta, JAI Vol $\quad 5 \quad$ No.1 Maret 2009:43-56. Fakultas Ekonomi UniversitasIslam Agung Semarang.

Ikatan Akuntan Indonesia. 2009. StandarAkuntansi Keuangan. Salemba Empat Jakarta.

Kadir Abdul, 2011. Faktor-Faktor Berpengaruh Terhadap Ketepatan Waktu Pelaporan Keuangan Perusahaan Manufaktur. Jurnal Akuntansi dan Manajemen Volume 12 Nomor 1. Sekolah Tinggi Ilmu Ekonomi Indonesia ,Banjarmasin.

Kartika Andi, 2009. Faktor-Faktor Yang Mempengaruhi Audit Delay di Indonesia (Studi Empiris Pada Perusahaan-Perusahaa LQ 45 Yang Terdaftar di Bursa Efek Jakarta), Jurnal Bisnis dan Ekonomi (JBE), Fakultas Ekonomi Universitas Stikubank Semaran

Kasmir. 2012. Analisis Laporan Keuangan. Jakarta : Rajawali Persada.

Kuswanto, Hedy.2014. Faktor-Faktor Yang Mempengaruhi Ketepatan Waktu Penyampaian Laporan Keuangan,Dharma Putra Semarang. 
Muhammad Ali Ustman. 2018. Analisis Faktor-Faktor Ketepatan Waktu Penyampaian Laporan Keuangan Perusahaan Sektor Barang Konsumsi. Universitas Islam Indonesia Yogyakarta

Meythi, 2005, Rasio Keuangan yang yang paling baik Untuk memprediksi Pertumbuhan Laba : Suatu Studi Empiris pada Perusahaan Manufaktur Yang terdaftar Di Bursa Efek Jakarta, Jurnal Ekonomi Dan Bisnis Indonesia, Vol.11

Munawir S.2004. Analisis Laporan Keuangan, Edisi Revisi. Liberti : Yogyakarta.

Ngestiana Wijayanti. 2009. Pengaruh Profitabilitas, Umur Perusahaan, Ukuran Perusahaan, dan Kepemilikan Publik Terhadap Ketepatan Waktu Pelaporan Keuangan Perusahaan. Universitas Sebelas Maret Surakarta.

Nurmiati. 2016. Faktor-faktor yang mempengaruhi ketepatan waktu pelaporan keuangan, Jurnal Ekonomi dan Manajemen, Volume 13, Nomor 2.

Owusu, Stephen dan Ansah. 2000. Timeliness Of Corporate Financial Reporting In Emerging Capital Market : Empirical Evidence From The Zimbabwe Stock Exchange. Accounting and Business Research.

Permatasari, V. Marlinda. 2012. Pengaruh Profitabilitas, Solvabilitas, Ukuran Perusahaan, Ukuran Kantor Akuntan Publik, dan Opini Auditor. Universitas Sanata Dharma, Yogyakarta.

Putri, Wandha Alzena.2018. Faktor-Faktor Yang Mempengaruhi Ketepatan Waktu Penyampaian Laporan Keuangan (Studi Empiris Pada Laporan Keuangan Perusahaan Manufaktur Yang Terdaftar Di Bei Tahun 2010-2016). Universitas Islam Indonesia, Yogyakarta

Qomary, N., Andini, R., \& Raharjo, K. (2016).Faktor-Faktor Yang Mempengaruhi Ketepatan Waktu Corporate Internet Reporting Pada Perusahaan Manufaktur Sektor Industri Food And Baverage Yang Terdaftar Di Bursa Efek Indonesia (Bei) Periode 2007-2013. Journal of Accounting, 2(2).

Rini Dwiyanti. 2010. Analisis Faktor-Faktor yang Mempengaruhi Pelaporan Keuangan Pada Perusahaan Manufaktur yang terdaftar di Bursa Efek Indonesia. Universitas Diponegoro, Semarang

Setiawan, Irfan Haris dan Dini Widyawati. 2014. "Faktor-Faktor Yang Mempengaruhi Tingkat Ketepatan Waktu Pelaporan Keuangan Perusahaan Manufaktur Di Indonesia". Jurnal Ilmu \& Riset Akuntansi. Vol.3, No.11, Hlm. 1-17.

Sianturi, Agnes Novaria Ekaristi. 2018. Pengaruh Kualitas Audit, Ukuran Perusahaan, Umur Perusahaan dan Opini Audit terhadap Ketepatan Waktu Pelaporan Keuangan pada Perusahaan Pertambangan yang Terdaftar di Bursa Efek Indonesia Tahun 2013-2016. Universitas Sumatera Utara, Medan

Tri Lestari Saputri, Riswan. 2015. Pengaruh Profitabilitas, Ukuran Perusahaan, Debt ToEquity Terhadap Ketepatan Waktu Penyampaian Laporan Keuangan(Studi Pada Perusahaan Asuransi Yang Terdaftar Di Bei). Jurnal Akuntansi \& KeuanganVol. 6, No. 1, Maret 2015

www.bapepam.go.id.

www.idx.co.id 